\title{
Revisiting the Nexus Between Inflation Targeting and the Build-Up of the Financial Imbalances
}

\author{
Adel Bogari ${ }^{1}$ \\ ${ }^{1}$ Assistant Professor- College of Business Administration, Al-Baha University, KSA \\ Correspondence: Adel Bogari, Assistant Professor- College of Business Administration, Al-Baha University, KSA.
}

Received: February 4, 2020

Accepted: March 2, 2020

Available online: March 3, 2020

doi:10.11114/aef.v7i2.4739

URL: https://doi.org/10.11114/aef.v7i2.4739

\begin{abstract}
The outbreak of the recent global financial crisis in 2007-2008 of the most developed economies, has spurred criticism that inflation targeting central banks may have neglected the build-up of financial imbalances. In other words the global financial and economic crisis highlights that central banks should be more effective in mastering financial instability, and should achieve an explicit goal of financial stability beyond their traditional emphasis on low inflation. In this paper, we aim to assess whether inflation targeting (IT) actually mattered as regards financial stability. Our empirical evidence has been conducted on a group of 41 emerging economies from which 20 economies adopt Inflation Targeting policy and 21 non Inflation Targeting economies as a group of control, over the period 2000-2017. To do this, we evaluate the time varying treatment effect of the IT's adoption on the banking system stability. Additionally using a variety of propensity score matching methods, we show that, on average inflation targeting has an insignificant effect on lowering banking system instability.
\end{abstract}

Keywords: inflation targeting, financial stability, treatment effect, propensity score matching. emerging economies

\section{Introduction}

In recent years, inflation targeting as a monetary regime has been gaining ground in both developed and emerging countries (Mishkin, 2004; Heenan et al. 2006). This monetary regime has been the subject of several studies that assessed its economic performance. At this level, evidence has pointed to its ability to maintain prices at lower levels (Mishkin, 1999; Johnson, 2002; Bean, 2009).

However, after the revolutionary financial changes triggered by the recent global financial crisis (2007-2008) and the progress in information and telecommunication technology, inflation targeting remains limited in time (Woodford, 2012).

Furthermore, the traditional theory of inflation targeting known by the Schwartz hypothesis (1995), assumes that price stability generates improvement in the financial system's performance. However, these assumptions disagree with those of other experts who believe that any decrease in price levels generates financial destabilization.

In other words, adoption of inflation targeting certainly allows for stabilized macroeconomic aggregates, yet this stabilization remains at odds with financial stability. More specifically, some economic fundamentals cannot resist exogenous chocks despite their robustness, generating thereafter a financial vulnerability that intensifies the impact of these chocks on the real economic sphere. Pierre and Luiz (2013).

In this respect and according to recent studies, central banks' concern with prices' stability threatens financial stability. Blanchard et al. (2010). This can be explained by the fact that a low and a stable consumer price index does not rapidly express any information reflecting financial imbalances, in particular the emergence of phenomena like asset bubbles and frictions in bank credit volume. Goodhart (2004).

In this regard, executing a price stability regime as the unique objective of monetary policy works at the expense of financial stability. This latter policy rigidness brought the relationship between price stability and financial stability into focus.

These changes in monetary perspectives brought to light new research trends that dealt with inflation targeting by including the economic stability dimension. However, this literature remains scarce and limited. Hence, our study aims at covering two dimensions. First, it looks for enriching the scarcity of the literature. Second, it aims at highlighting our 
contribution to the previous literature by including the banking stability dimension. To this end, our study tries to determine the impact of inflation targeting on banking stability in a sample of emerging countries, using the treatment effect method.

Our paper then is structures as follows: Section 2 presents an overview on the theoretical relationship between an inflation targeting policy and financial stability. Section 3 reviews the earlier studies that empirically examined the relationship between these two variables. Section 4 presents our research methodology. Section 5 presents and discusses the obtained results. Finally, section 6 concludes the paper.

\section{Theoretical Relationship Between Inflation Targeting and Financial Stability}

During the 1990s, the emergence of inflation targeting as a recalibrating monetary policy regime, gained ground not only in developed countries but also in emerging ones. According to (Mishkin, 2004, 2011; Heenan et al. 2006) inflation targeting consists of five basic components. These are an institutional commitment towards price stability, an evolutionary, a developed communication system, and the explicit and public disclosure of time-bound nominal inflation targets in the mid-term. Furthermore, an inflation-targeting regime should rely on a high degree of responsibility as well as on an inclusive information strategy manifesting itself in taking into account information about monetary aggregates and exchange rates. Provision of these, would allow authorities to better set up a monetary policy instrument.

These new perspectives present an opportunity for several researchers to further examine the macroeconomic performance of inflation targeting. Among these researchers, Roger (2010) proved that inflation targeting allows for controlling and stabilizing prices as well as further rationalizing anticipations allowing inflation targeting countries to move to a disinflation period. Indeed, according to Gonçalves and Carvalho (2009), disinflation does not penalize loss of output for inflation targeters (ITers). In other words, the weight of this loss is less important for ITers than for non-ITers because of a high degree of transparency and communication output practiced by monetary authorities. In addition, Brito (2010) questions this result as he considers a loss of output can be generated following a disinflation period.

Despite the ambiguous real effect of low inflation on macroeconomic aggregates, disinflation generates, ceteris paribus, a positive effect on financial stability. This assumption has been initially developed by the Schwartz hypothesis (1995) presuming that an instable price generates uncertain future real investment returns. Furthermore, the Schwartz hypothesis is not a financial crisis theory but rather a hypothesis that explains how price instability may generate financial instability and increase the probability of a crisis shock. However, this hypothesis proves that monetary stability improves financial stability, while explaining that a maintained inflation rate encourages borrowing and speculative investment as an increase in prices will be anticipated.

With an unstable inflation, default risk increases because of inflation control via an increase in interest rates, which reduces depositors' income. Subsequently, a deterioration in bank spread is highly likely, which may lead to a panic in the banking system causing a failure of financial institutions. Several researchers support the Schwartz hypothesis (1995), like (Bordo and Wheelock, 1998; Bordo et al. 2001; Issing, 2003) who believe that monetary stability eliminates financial instability sources.

With the recent revolutionary financial changes following the global financial crisis (2007-2008), it seems that inflation targeting remains limited and unable to resist crises. Furthermore, despite the robustness of some economic fundamentals, these latter cannot resist exogenous chocks, leading thereafter to financial vulnerability. Pierre and Luiz (2013). In this respect, central banks had to revise their role in stabilizing prices so that they become tantamount to promoting financial stability. Following these changes, several economists like (White, 2006; Issing, 2009; Blanchard et al. 2010; Fouejieu, 2013) contested and challenged the Schwartz hypothesis (1995). These authors pointed to the negative effect of monetary stability on financial stability. Such as assumption may be explained by the fact that an expansionist monetary policy, based on a low interest rate, pushes banks to take additional risks by means of over credit granting like in the pre-crisis period of 2008. Such a move generated a default risk leading to a banking panic. Consequently, these researchers( Borio and Zhu, 2008; Tabak et al. 2013), suggest to improve inflation targeting by integrating financial stability as an objective to reach support this point of view assuming that low interest rates in the short term generate an increase in investors' speculations, thus leading to an increase in asset price bubbles and consequently threatening financial stability.

\section{Literature Review}

The recent literature on inflation targeting has expanded to incorporate the financial stability dimension within the framework of this new monetary policy regime. However, from a Schwartz hypothesis (1995) perspective, these studies remain controversial without necessary reaching an ultimate consensus about whether to confirm or reject the positive correlation between price stability and financial stability. In this respect, (Bordo et al. 2001; Bordo and Landon-Lane 
2010; Issing, 2003) studied the impact of aggregate price chocks on the financial stability index in the US from 1870 to 1997, by estimating a dynamic probit model and an Ordinary Least Squares (OLS) regression to estimate individual series in terms of an instability index. The results indicate that a non-anticipated price movement generates an instability in the US economy, confirming thus the Schwartz hypothesis. These results are consistent with those of Woodford (2012), which indicate that monetary stability eliminates financial stability sources like salary price spirals.

This field of study has expanded by recent studies like those of (Fazio et al. 2014, 2015) who studied the impact of inflation targeting on banking system stability, measured by a Z-score calculated for a sample of 5500 commercial banks operating in 70 countries ( 22 targeters and 48 non-targeters) observed from 1998 to 2012. The authors proved that inflation targeters dispose of a more stable banking system than non-targeting ones. More specifically, risk taking for commercial banks belonging to targeters and having a strong communication and better responsibility is lower than for those belonging to non-targeters.

These different studies explain why central banks pursue price stability given that this latter is consistent with the financial system stability hypothesis. Furthermore, these above-mentioned studies that supported the Schwartz hypothesis have been challenged by (Borio et al .2003; Rajan, 2005; White, 2006; Leijonhufvud, 2007), who indicated that the premise that price stability is beneficial for financial stability should be revised. Because stable low inflation makes the financial system more vulnerable, this can be explained by the fact that a stable inflation reflects an optimistic perception of future economic development. Whereas this false perception may increase excessively stock values threatening then the financial market.

Taylor (2009) who found that low interest rates reduce the occurrence probability of real estate prices bubbles has confirmed these assumptions. In other words, according to these results, a central bank that maintained its credibility via a low inflation rate jeopardizes the financial system. Consequently, financial instability is revealed in the emergence of financial crises. As for Frappa and Mesonnier (2010), they studied the relationship between inflation targeting and the formation of real estate price bubbles in a sample of 17 industrialized countries, among them we find 9 inflation targeters and 8 non-targeters observed from 1980 to 2007. The methodology used in this study was Average Treatment Effect approach in order to prove that an inflation targeting regime acts positively on the formation of real estate bubbles and thus it reflects a risk for financial stability. In this same context, and in order to explore the relationship between monetary policy and financial stability, Munoz and Schmidt-Hebbel (2012) examined monetary policy decisions for 28 emerging and developed countries from 1994 to 2011. In addition to including exchange rates, the authors integrated financial stability variables into the Taylor rule. These variables are private credit development and stock price. The results support the «leaning against the wind» hypothesis reflecting central banks' concern with financial stability. These results are consistent with those of Fouejieu (2017) who studied a sample of 26 emerging market economies including 13 ITers, and13 non-ITers. The analysis used quarterly data over the period 2000Q1-2010Q4, to combine information from a number of financial and macroeconomic indicators to construct a composite index measuring the financial stability. The main findings reveal that on average, ITers are financially more vulnerable than non ITers. The analysis of reaction functions suggest that contrary to their counterparts, 8 of the 13 ITers central banks respond to financial imbalances with tighter policy. This study follows replicates the reasoning of (Cecchetti et al. 2000; Bordo and Olivier, 2002) who studied a sample of Organization for Economic Co-operation and Development (OECD) countries from 1970 to 2001. By estimating the Taylor rule, the authors concluded to a disagreement about whether inflation targeting ensures by itself financial stability or it does so jointly with output stability. This has been confirmed by (Roubini, 2006), who found controversial results about the relationship between monetary stability and asset bubbles stability.

The debate on the impact of inflation targeting on financial stability remains controversial because sometimes prices stability improves financial stability and sometimes it threatens it with a serious destabilization. For this reason, our study tries to enrich the limited relevant literature in order to cut through this line of controversial debate.

\section{Methodology}

\subsection{Data and Descriptive Analyses}

In this section, we try to estimate the treatment effect of inflation targeting on a banking system stability. For this purpose, our study examines a sample of 763 commercial banks operating in 41 emerging countries observed between 2000 and 2017. More specifically, our sample is as follows: 20 ITers emerging countries (treatment group) and 21 non-ITers countries (control group). Our reasons to select the treatment group follow those of Lin and Ye (2009). Furthermore, our control group has been selected in response to the criterion defined by Lin and Ye (2009) of country size and economic growth. Table 1 below presents the different countries and their sampling dates. Moreover, like (Levya, 2008; Lucotte, 2012), we retain two adoption periods of inflation targeting. These are partial adoption (IT_PA), and full-fledged adoption (IT_FF). 
Indeed, as detailed in appendix A, variables used to assess the relationship between inflation targeting and banking system stability are as follows:

The dependent variable is banking stability measured by a Z-score, which measures stability of each bank $\mathrm{i}$ in country $\mathrm{j}$ in year t. This variable is written as follows:

$\mathrm{Z}$-score $=\mathrm{ROA}+\mathrm{EQTA} / \sigma(\mathrm{ROA})$

With:

ROA: Return on average assets represents the average performance of the bank's assets.

EQTA: Equity to total assets as a measure of bank capitalization.

$\sigma(\mathrm{ROA})$ : The standard deviation of ROA as a proxy for returns volatility.

The independent variable: Inflation targeting is measured by the annual growth in the Consumer Price Index (CPI).

The data are taken from different sources: The World Bank's World Development Indicator, The International Monetary Fund's International Financial Statistics, and the Van Dijk Bankscope.

Table 1. List of the sample countries with dates of inflation targeting adoption

\begin{tabular}{|c|c|c|c|}
\hline \multicolumn{2}{|c|}{ IT countries } & \multicolumn{2}{|c|}{ Non-IT countries } \\
\hline & Partial adoption & Fully -Fledged Adoption & Algeria \\
\hline Brazil & 1999 & 1999 & Argentina \\
\hline Chile & 1991 & 2000 & Bulgaria \\
\hline Colombia & 2000 & 2000 & Cote d'Ivoire \\
\hline Czech Republic & 1998 & 1998 & Dominican Republic \\
\hline Ghana & 2007 & 2007 & Ecuador \\
\hline Guatemala & 2005 & 2005 & Egypt \\
\hline Hungary & 2001 & 2001 & El Salvador \\
\hline Indonesia & 2005 & 2005 & India \\
\hline Israel & 1992 & 1997 & Malaysia \\
\hline Mexico & 1995 & 2001 & Morocco \\
\hline Peru & 1994 & 2002 & Niger \\
\hline Philippines & 2002 & 2002 & Nigeria \\
\hline Poland & 1999 & 1999 & Pakistan \\
\hline Roumania & 2005 & 2005 & Russia \\
\hline Serbia & 2006 & 2006 & Senegal \\
\hline Slovakia & 2005 & 2005 & Singapore \\
\hline South Africa & 2000 & 2000 & Tunisia \\
\hline South Korea & 1998 & 1998 & Uruguay \\
\hline Thailand & 2000 & 2000 & Venezuela \\
\hline Turkey & 2006 & 2006 & \\
\hline
\end{tabular}

Source : Lucotte ( (2012)

Fig.1 compares the average Z-score for ITers and non-ITers during the different sampling periods. Specifically, first, we try to compare the average Z-score for ITers and non-ITers over the period 2000-2017. Then, like Ball and Sheridan (2003), we compare banking stability indicator for ITers and non-Iters in the post-inflation targeting adoption period for both partial and fully fledged adoption. Fig. 1 shows that ITers dispose of a more stable banking system than non-ITers during the post-targeting period, but only for fully fledged adoption (Post-FF), as the Z-score for ITers is higher than that of non-ITers, which proves that ITers' banking system is close to stability. 


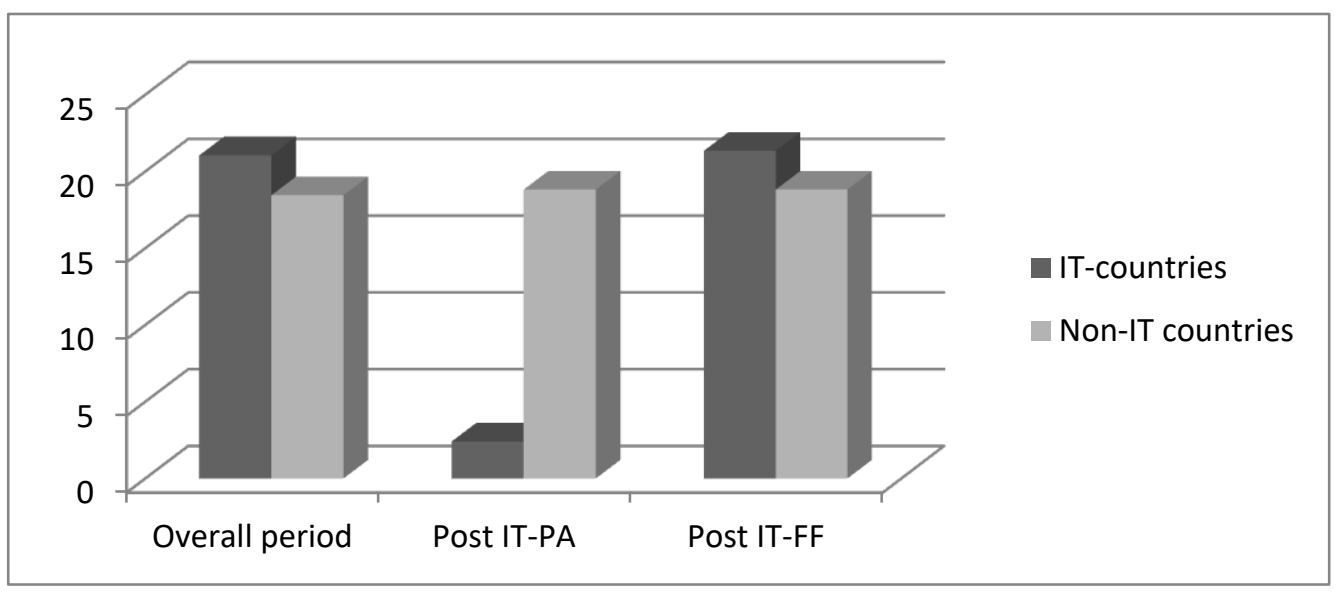

Figure 1. Average Z-score: IT vs. non-IT countries

Fig. 2 compares the average Z-score for ITers during the pre- and post-adoption periods. It should be noted that on average these countries managed to stabilize their banking system during the post-adoption period, but only for fully fledged adoption (Post IT-FF). According to these descriptive statistics, the implementation of an inflation targeting regime is beneficial for emerging ITers countries as their banking system instability is reduced. Nevertheless, we cannot validate this relationship by limiting ourselves uniquely to this descriptive analysis. The relationship between inflation targeting and banking stability of emerging countries will be examined further with an econometric analysis. See appendix B. For more details.

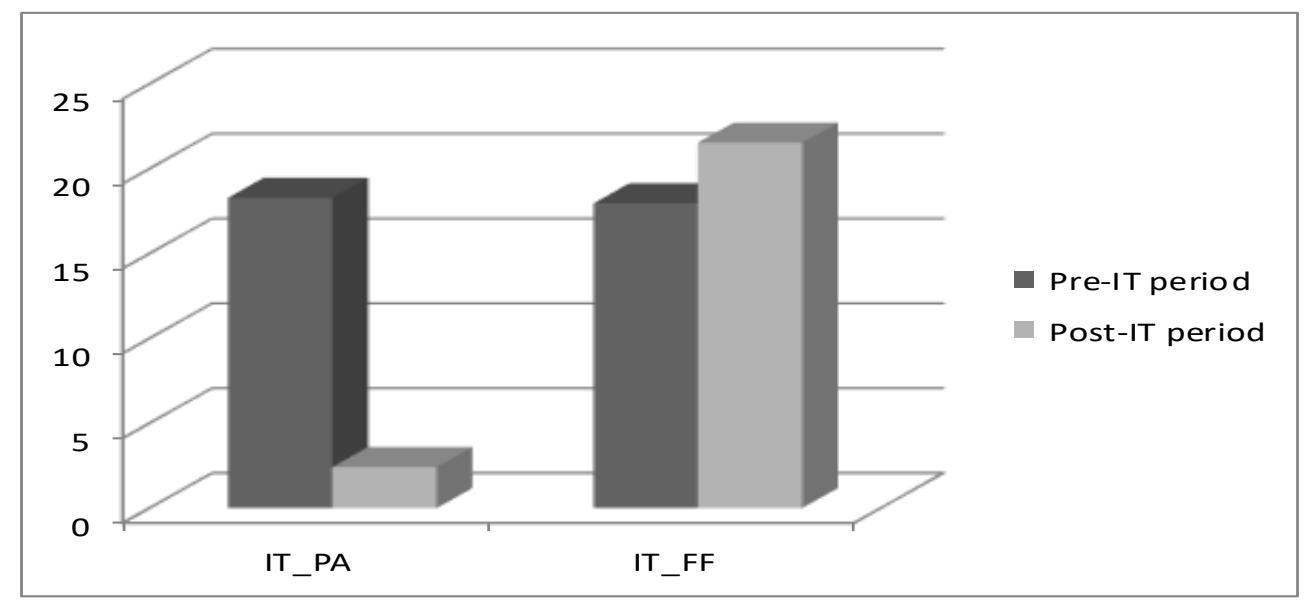

Figure 2. Average Z-score: pre-IT vs. post-IT periods

\subsection{Treatment Effect and Selection Bias}

In this section, our aim is to test the extent to which inflation targeting adoption affects banking system stability in emerging countries. More specifically, we test whether ITers' banking systems are more stable than those of non-ITers. To this end, a new econometric methodology has been developed in macroeconomics. This is the propensity score matching method initially proposed by Rubin (1977), and developed more recently by Heckman et al. (1998).

Indeed, in this study, our focus is determining how banking stability as measured by a Z-score would have evolved in emerging ITers, if the latter did not opt for inflation targeting. Note that this evolution is by definition unobservable. Similarly, and taking the opposite case, what would have non-ITers banking stability been if the latter had decided to adopt this monetary policy. In order to evaluate this causal effect, it is necessary to examine banking stability indicators by comparing ITers' and non-ITers' Z-scores, and determining whether, on average, ITers would have disposed of a more stable banking system, statistically different from that of non-ITers.

However, in order to assess the treatment effect of inflation targeting for ITers, it is useful to estimate the average treatment effect (ATT) on the treated, written as follows: 


$$
\mathrm{ATT}=\mathrm{E}\left[\mathrm{Y}_{\mathrm{i} 1} \mid \mathrm{D}_{\mathrm{i}}=1\right]-\mathrm{E}\left[\mathrm{Y}_{\mathrm{i} 0} \mid \mathrm{D}_{\mathrm{i}}=1\right]
$$

With:

D: a binary variable that takes 1 in case of inflation targeting adoption, and 0 otherwise.

$Y_{i 1} \mid D_{i}=1$ : The outcome value when banking system stability as measured by a Z-score would have been observed if the country had adopted an inflation targeting policy.

$Y_{i 0} \mid D_{i}=1$ : The outcome value when banking system stability would have been observed if the country had not opted for inflation targeting.

The difficulty encountered while estimating the average treatment effect on the treated (ATT) is non-observing the term $Y_{i 0} \mid D_{i}=1$. More specifically, we cannot observe a variation in financial stability of a targeting country that has not adopted such a policy. If the choice of targeting countries is random, ATT would be obtained by comparing the average treatment effect of the target group (treatment group) with that of the non-target group (control group).

\subsection{Propensity Score Matching Method and Conditioning Variables}

\subsubsection{Propensity Score Matching}

In the recent literature on inflation targeting, some authors like (Lin and Ye 2007, 2009; De Mendonça and De Guimarães. 2012; Lucotte 2012) have used non-parametric propensity score matching methods. This relatively intuitive methodology consists first in matching each ITer with a non-ITer "twin" country, with similar economic and institutional characteristics. Then, we proceed to considering the latter's outcome value as an outcome counterfactual to the ITer country, so that this matching method would have the advantage of reducing selectivity bias.

The main idea behind matching is to use a control group to replicate a randomized experiment. Moreover, this method is grounded on two basic hypotheses. The first is the conditional independence hypothesis $\left(Y 0, \quad \mathrm{Y} 1{ }^{\perp} \mathrm{D} \mid \mathrm{X}\right)$. Indeed, this hypothesis assumes that, with conditional variables $\mathrm{X}$, the output value reflected by the banking stability indicator (Z-score) should be independent of the dummy variable (inflation targeting adoption). Under this assumption, equation 1 is rewritten as follows.

$$
\mathrm{ATT}=\mathrm{E}\left[\mathrm{Y}_{\mathrm{i} 1} \mid \mathrm{D}_{\mathrm{i}}=1, \mathrm{X}_{\mathrm{i}}\right]-\mathrm{E}\left[\mathrm{Y}_{\mathrm{i} 0} \mid \mathrm{D}_{\mathrm{i}}=0, \mathrm{X}_{\mathrm{i}}\right]
$$

We have replaced $E\left[Y_{i 0} \mid D_{i}=1\right]$ with the following observable: $E\left[Y_{i 0} \mid D_{i}=0, X_{i}\right]$. In other words, the matching method consists in matching the treated units with those of the control group by similar $\mathrm{X}$ values.

This method becomes difficult to apply, since the number of the covariates of $\mathrm{X}$ increases. To mend for this, Rosenbaum and Rubin (1983) propose to match the treated units with those of the control group, referring to their propensity scores. Indeed, these propensity scores represent the probability of inflation targeting adoption, conditioned by $\mathrm{X}$ variables. Moreover, propensity scores are estimated via simple Logit or Probit models.

In addition, the propensity score matching method rests on a second hypothesis, "the common support condition" (p $\left.\left(\mathrm{X}_{\mathrm{i}}\right)<1\right)$. This assumption assumes the existence of some comparable control units for each treated unit. Defining the common support area is based on the "Min-Max" method developed by Dehejia and Wahba (1999), and is commonly used in the literature.

\subsubsection{Conditioning Variables}

In order to estimate propensity scores, we refer to the conditioning variables that affect both the outcome value and the treatment variable. Indeed, these variables reflect institutional preconditions, in particular the lagged inflation rate for one period (INF_1) and the independence of the central bank within 5 years (TOR_5). For these variables, a negative relationship with inflation targeting is expected. As for the variables of degree of de facto flexibility of exchange rate $(\mathrm{EXCH})$ and private sector credit level (CRED), a positive relationship with inflation targeting is expected. The second group of conditioning variables is presented by broad money growth (BMG), trade openness rate (OPEN), and GDP growth per capita (GDPpc_G), which are expected to have a negative impact on inflation targeting adoption. The expected sign of democracy indicator presented by (POLITY2) is positive, which implies a positive effect on inflation targeting adoption.

\section{Results}

\subsection{Estimation of Propensity Scores}

In what follows, we report on propensity scores matching, in terms of the average treatment effect on the treated, estimated as:

$$
\mathrm{ATT}=\mathrm{E}\left[\mathrm{Y}_{\mathrm{i} 1} \mid \mathrm{D}_{\mathrm{i}}=1, \mathrm{p}\left(\mathrm{X}_{\mathrm{i}}\right)\right]-\mathrm{E}\left[\mathrm{Y}_{\mathrm{i} 0} \mid \mathrm{D}_{\mathrm{i}}=0, \mathrm{p}\left(\mathrm{X}_{\mathrm{i}}\right)\right]
$$


To estimate propensity scores, the Probit model was used. In this case, the dependent variable is inflation targeting adoption whose scores are reported in Table 2 below. Two sampling periods are distinguished; partial adoption and fully fledged adoption.

These results indicate that all the coefficients of the conditioning variables are statistically significant at the $1 \%$ and $5 \%$ levels for both partial adoption and Fully Fledged adoption, with the exception of the coefficients of the variables OPEN and BMG. The latter is statistically insignificant for both partial and fully fledged adoption, while the OPEN variable is statistically insignificant for fully fledged adoption.

Moreover, most of the coefficients of the conditioning variables have signs as expected by the literature. Nevertheless, exceptions are the signs of the coefficients of the TOR and CRED variables for partial adoption. The same is true for the coefficients of CRED and OPEN for fully fledged adoption. Indeed, this finding corroborates that in the literature, suggesting that any country with exchange rate flexibility, better democracy, high inflation lags and low macroeconomic performance is likely to adopt inflation targeting in its partial and fully fledged versions. (Lin and Ye 2007, 2009; Lucotte , 2012).

As for the other conditioning variables, dependence of inflation targeting adoption to these variables varies across sampling periods. Specifically, the central bank's degree of independence (TOR_5) and domestic credit to the private sector (CRED) directly relate to the likelihood of inflation targeting adoption, yet in opposite terms to those proved by the literature for both partial and fully fledged adoption.

Table 2. Probit estimates propensity scores

\begin{tabular}{|c|c|c|}
\hline Variables & IT_PA & IT_FF \\
\hline \multirow[t]{2}{*}{ GDPpc_G } & $-0.083^{* * * *}$ & $-0.067^{* \ldots+2}$ \\
\hline & $(0.016)$ & $(0.013)$ \\
\hline \multirow[t]{2}{*}{ INF_1 } & $-0.048^{* * * *}$ & $-0.034^{* * *}$ \\
\hline & $(0.007)$ & $(0.005)$ \\
\hline \multirow{2}{*}{ BMG } & 0.008 & 0.005 \\
\hline & $(0.004)$ & $(0.003)$ \\
\hline \multirow[t]{2}{*}{ CRED } & $-0.010^{* * * *}$ & $-0.007^{* *}$ \\
\hline & 0.003 & $(0.003)$ \\
\hline \multirow[t]{2}{*}{ OPEN } & 0.001 & $0.005^{* * *}$ \\
\hline & $(0.002)$ & $(0.002)$ \\
\hline \multirow[t]{2}{*}{$\mathrm{EXCH}$} & $0.380^{* * *}$ & $0.278^{* * * *}$ \\
\hline & $(0.029)$ & $(0.022)$ \\
\hline \multirow[t]{2}{*}{ TOR_5 } & $11.273^{* * *}$ & $-7.664^{* * * *}$ \\
\hline & $(0.905)$ & $(0.595)$ \\
\hline \multirow[t]{2}{*}{ POLITY2 } & $1.007^{* * * *}$ & $0.699^{* * * *}$ \\
\hline & $(0.092)$ & $(0.068)$ \\
\hline Number of observations & 1191 & 1191 \\
\hline Pseudo- $\mathrm{R}^{2}$ & 0.5703 & \\
\hline
\end{tabular}

Note: Values in parentheses are standard deviations.

$* * *, * *$, represent respectively the statistical significance at threshold of $1 \%, 5 \%$.

\subsection{Matching Results}

Before proceeding to estimating matching, we should first establish the common support region. To this end, we used the Dehejia and Wahba's (1999) method, which consists in eliminating observations of the control group whose propensity scores are above the maximum or below the minimum. This ensures those observations of the treated and those of the untreated share the same support.

The ATT on the Treated estimate of banking stability is reported in Table 3. The first three columns represent the results by the nearest-neighbor matching estimator. The fourth column represents the results of the Local linear regression-matching estimator. The last column represents the results of the Kernel matching estimator.

In this table, all ATTs estimated by the three estimators are statistically insignificant for both partial and fully fledged adoption. This proves that inflation targeting does not affect banking stability. More specifically, the evolution of the Z-score reflecting the degree of banking insolvency can not be explained by inflation targeting adoption. This indicates that the effect of inflation targeting on banking stability is virtually absent, because of banking and financial market in emerging economies are less developed at the time of adoption. On the other hand, this motivates the introduction of some reforms, which should necessarily be undertaken and implemented during the pre-adoption period and that their late or even post-adoption implementation will not have the expected effect on macroeconomic performance. In other words, a well-developed and healthy banking and financial sector represents not only a prerequisite for the 
implementation of inflation targeting, but also a better implementation context of monetary policy, allowing thus for an inflation targeting policy efficient in terms of financial and economic stability.

Table 3. Matching estimates of treatment effect on the Banking Stability

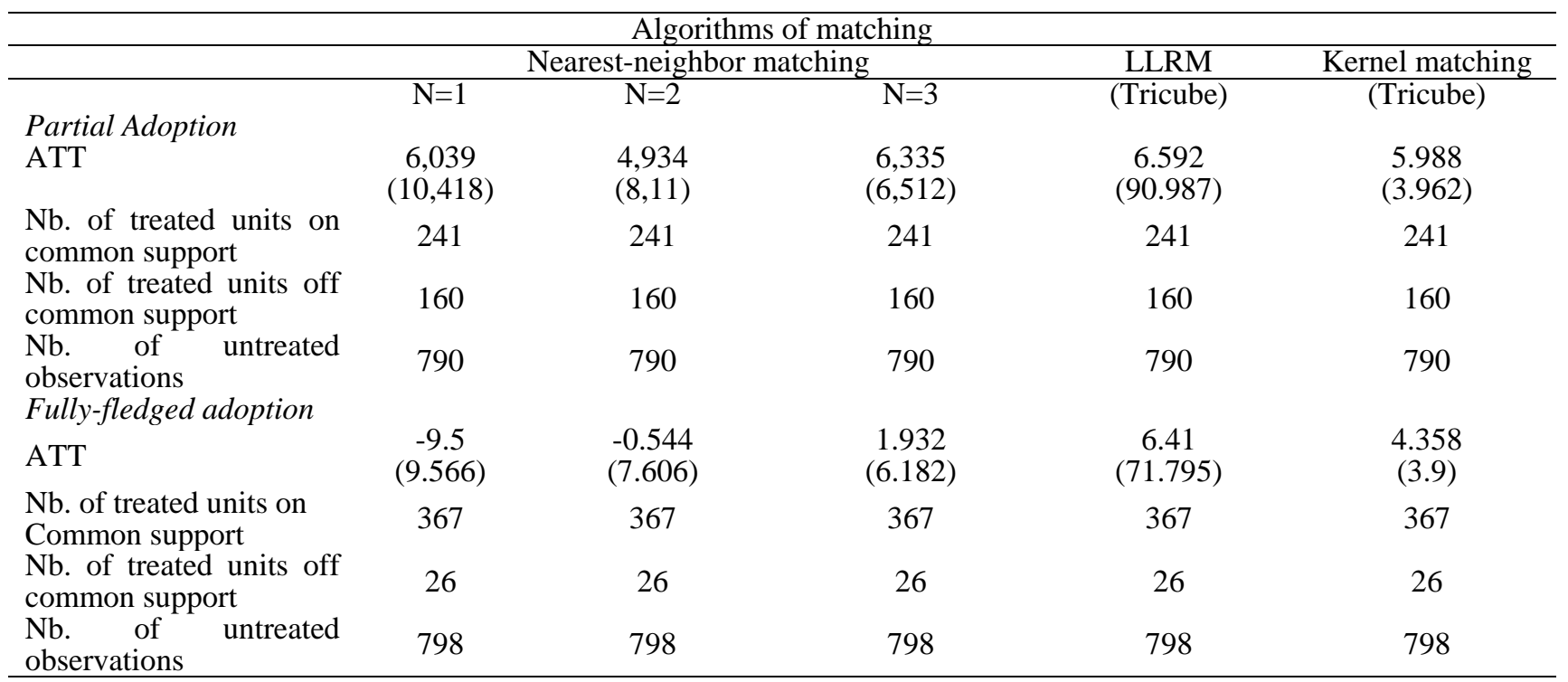

Note: Bootstrapped standard errors based on 2000 replications are in parentheses.

\section{Conclusion and Policy Implications}

This paper essentially reports on a study dealing with the relationship between inflation targeting policy and financial stability. In this study, we examined a sample of emerging countries in an attempt to assess whether the banking system of ITers is more fragile than that of non-ITers. Referring to the literature on inflation targeting, we opted for the treatment effect method by applying the propensity score matching method.

Our results pointed to a statistically insignificant relationship between inflation targeting adoption and banking stability. Specifically, maintaining inflation at low levels does not affect banking stability of emerging countries.

In other words, it is concluded that because the banking and financial systems of emerging countries are less developed, any effect of inflation targeting on banking stability is undermined, and that its late or even post-adoption implementation will not have the desired effect on macroeconomic performance.

The policy implications of this study relate to emerging countries considering some reforms and preconditions before adopting inflation targeting. Such reforms serve these countries not only as a ground to set up an institutional framework conducive to an efficient inflation targeting, but also as prerequisites to benefit from the expected effects of this regime on both economic performance and financial stability.

\section{References}

Ball, L., \& Sheridan, N. (2003). Does inflation targeting matter? NBER Working Paper 9577. Cambridge, MA. https://doi.org/10.3386/w9577

Bean, C. (2009). The meaning of internal balance thirty years. Econ.J., 119, 442-460. https://doi.org/10.1111/j.1468-0297.2009.02315.x

Blanchard, O., Dell'Ariccia, G., \& Mauro, P. (2010). Rethinking macroeconomic policy. IStaPosition Note. https://doi.org/10.2139/ssrn.1555117

Bordo, M. D., \& Landon-Lane, J. S. (2010). The global financial crisis of 2007-08: is it unprecedented? NBER Working Paper 16589. https://doi.org/10.3386/w16589

Bordo, M. D., \& Olivier, J. (2002). Monetary policy and asset prices: does benign neglect make sense? Int.Financ., 5(2), 139-164. https://doi.org/10.1111/1468-2362.00092

Bordo, M. D., \&Wheelock, D. W. (1998). Price stability and financial stability: the historical record. Federal Reserve Bank of St Louis Review, 41-62. https://doi.org/10.20955/r.80.41-62

Bordo, M. D., Dueker, M. J., \&Wheelock, D. C. (2001). Aggregate price shocks and financial instability: a historical 
analysis. Working Paper 2000-005B. FRB of Saint Louis. https://doi.org/10.3386/w7652

Borio, C., \& Zhu, H. (2008). Capital regulation risk taking and monetary policy: a missing link in the transmission mechanism ? BIS Working Paper 268. https://doi.org/10.2139/ssrn.1334132

Borio, C., English, B., \& Filardo, A. (2003). A tale of two perspectives: old or new challenges for monetary policy? BIS Working Paper 127. https://doi.org/10.2139/ssrn.844208

Cecchetti, S. G., Hans Genberg, J. L., \& Sushil, W. (2000). Asset prices and central bank policy. International Center for Monetary and Banking Studies, Geneva. 140.

De Mendonça, H. F., \& De Guimarães e Souza, G. J. (2012). Is inflation targeting a good remedy to control inflation? J. Dev. Econ., 98(2), 178-191. https://doi.org/10.1016/j.jdeveco.2011.06.011

Dehejia, R., \& Wahba, S. (1999). Causal effects in non-experimental studies: re-evaluating the evaluation of training programs. J.Americ.Statis. Asso., 94(448), 1053-1062. https://doi.org/10.1080/01621459.1999.10473858

Fazio, D. M., Tabak, B. M., \& Cajueiro, D. O. (2014). Inflation targeting and banking system soundness: a comprehensive analysis. Working Paper ISSN 1518_3548. Banco Central Do Brasil. https://doi.org/10.1016/j.jbankfin.2015.05.016

Fazio, D. M., Tabak, B. M., \& Cajueiro, D. O. (2015). Inflation targeting: is IT to blame for banking system instability? J.Bank.Financ.

Fouejieu, A. (2013). The concern of financial stability in inflation targeting regime: evidence from emerging countries. Universite d'Orleans, mimeo.

Fouejieu, A. (2017). Inflation targeting and financial stability in emerging markets. Econ.Model., 60, 51-70. https://doi.org/10.1016/j.econmod.2016.08.020

Frappa, S., \& Mesonnier., J. S. (2010). The housing price boom of the late 1990s: did inflation targeting matter? J.Financ.Stab, 6, 243-254. https://doi.org/10.1016/j.jfs.2010.06.001

Gonçalves, C. E. S., \& Carvalho, A. (2009). Inflation targeting matters: evidence from OECD economies sacrifice ratios. J.Mon.Cred.Bank., 41, 224-243. https://doi.org/10.1111/j.1538-4616.2008.00195.x

Goodhart, C. A. E. (2004). Some new directions for financial stability? The Per Jacobsson Lecture, Zurich.

Heckman, J. J., Ichimura, H., \& Todd, P. (1998). Matching as an econometric evaluation estimator. Rev. Econ. Stud., 65, 261-294. https://doi.org/10.1111/1467-937X.00044

Heenan, G., Peter, M., \& Roger, S. (2006). Implementing inflation Targeting: institutional arrangements target design and communication . IMF Working Paper. 06, 278. https://doi.org/10.5089/9781451865387.001

Issing, O. (2003). Monetary and financial stability: is there a trade off ?paper presented at a BIS Conference.

Issing, O. (2009). Asset prices and monetary policy. The Cato Journal Winter.

Johnson, D. R. (2002). The effect of inflation targeting on the behavior of expected inflation: evidence from an 11 country panel. J.Monet. Econ., 49, 1521-1538. https://doi.org/10.1016/S0304-3932(02)00181-2

Leijonhufvud, A. (2007). Monetary and financial stability. CEPR Policy Insight.14.

Levya, G. (2008). The choice of inflation targeting. Working Paper 475. Central Bank of Chile, Santiago.

Lin, S., \& Ye, H. (2007). Does inflation targeting really make a difference?: evaluating the treatment effect of inflation targeting in seven industrial countries. J. Monet. Econ., 54, 2521-2533. https://doi.org/10.1016/S0304-3932(02)00181-2

Lin, S., \& Ye, H. (2009). Does inflation targeting make a difference in developing countries? J. Dev. Econ. 89, 118-123. https://doi.org/10.1016/j.jdeveco.2008.04.006

Lucotte, Y. (2012). Adoption of inflation targeting and tax revenue performance in emerging market economies: an empirical investigation. Econ. Syst., 387(20). https://doi.org/10.1016/j.ecosys.2012.01.001

Mishkin, F. S. (1999). International experiences with different monetary policy regimes. J. Monet.Econ., 43, 579-605. https://doi.org/10.1016/S0304-3932(99)00006-9

Mishkin, F. S. (2004). Can inflation targeting work in emerging market countries? NBER Working Paper. 10646. https://doi.org/10.3386/w10646

Mishkin, F. S. (2011). Monetary policy strategy: lessons from the crisis. NBER Working Paper 16755. https://doi.org/10.3386/w16755 
Mishkin, F. S., \& Schmidt-Hebbel, K. (2007). Does inflation targeting make a difference? NBER Working Paper No.12876. https://doi.org/10.3386/w12876

Munoz, F., \& Schmidt Hebbel, K. (2012). Do the world's central banks react to financial markets in financial deepening macro stability and growth in developing countries. IMF Working Paper, Washington.

Pierre, R. A., \& Luiz A. P. S. (2013). Inflation targeting and financial stability: a perspective from the developing world. Working Paper, Banco Central do Brasil. 1-116.

Rajan, R. (2005). Has financial development made the world riskier in the Greenspan Era: lessons for the future proceedings of the FRB of Kansas city. Econ. Sympo. Jackson Hole., 313-369. https://doi.org/10.3386/w11728

Roger, S. (2010). Inflation Targeting turns 20. J.Financ.Dev. IMF Working paper, 47(1). https://doi.org/10.5089/9781451873832.001

Rosenbaum, P. R., \& Rubin, D. B. (1983). The central role of the propensity score in observational studies for causal effects. Biometrika., 70(1), 41-55. https://doi.org/10.1093/biomet/70.1.41

Roubini, N. (2006). Why central banks should burst bubbles. Int. Financ, 9(1), 87-107. https://doi.org/10.1111/j.1468-2362.2006.00032.x

Rubin, D. (1977). Assignment to treatment group on the basis of a covariate. J. Educ. Stat., 2, 1-26. https://doi.org/10.3102/10769986002001001

Schwartz, A. (1995). Why financial stability depends on price stability. Econ Aff., 15(4), 21-25. https://doi.org/10.1111/j.1468-0270.1995.tb00493.x

Tabak, B. M., Laiz, M. T., \& Cajueiro, D. O. (2013). Financial stability and monetary policy: the case of Brazil . Revista Brasileira de Economia., 67(4), 403-413. https://doi.org/10.1590/S0034-71402013000400003

Taylor, J. B. (2009). The financial crisis and the policy responses : an empirical analysis of what went wrong. NBER Working Paper 14631. https://doi.org/10.3386/w14631

White, W. (2006). Is price stability enough? BIS Working Papers 205. https://doi.org/10.2139/ssrn.900074

Woodford, M. (2012). Inflation targeting and financial stability. NBER Working Paper 17967. https://doi.org/10.3386/w17967

\section{Notes}

Note 1. The two selection criteria of the control group assume that any country with a Gross Domestic Product/capita at least as high as the poorest targeting country and with a population at least as important as the least populated targeting country, should be excluded from the control group.

Note 2. Partial adoption is known by incomplete preconditions necessary to inflation targeting adoption as well as a lack of implementation of this regime's operational framework like publication of annual reports on expected inflation rates (Mishkin and Schmidt-Hebbel, 2007).

Note 3. Fully fledged adoption denotes undertaking some prerequisites necessary to the implementation of inflation targeting.

Note 4. Note that Slovakia abandoned the IT in 2009 and joined the euro area. 
Appendix A. Variables' definitions and sources

\begin{tabular}{|c|c|c|}
\hline Variables & Definition & Sources \\
\hline IT & $\begin{array}{l}\text { Binary variable taking the value } 1 \text { if the country } \\
\text { adopt the inflation-targeting regime at the } \\
\text { period t, and } 0 \text { otherwise. }\end{array}$ & Levya (2008). \\
\hline Z-Score & $\begin{array}{l}\text { Indicator of banking stability. The index that } \\
\text { measures degree of stability of banks. }\end{array}$ & $\begin{array}{l}\text { Author calculations based on Van Dijk Bank Scope database } \\
2018 \text {. }\end{array}$ \\
\hline GDPpc_G & Real GDP per capita growth. & $\begin{array}{l}\text { World Development Indicators (WDI) are now } \\
\text { available free on the World Bank's website at: } \\
\text { http://data.worldbank.org/ }\end{array}$ \\
\hline INF_1 & $\begin{array}{l}\text { One-year lagged inflation rate (as annual } \\
\text { change of the CPI). }\end{array}$ & $\begin{array}{l}\text { World Development Indicators (WDI) are now } \\
\text { available free on the World Bank's website at: } \\
\text { http://data.worldbank.org/ }\end{array}$ \\
\hline TOR_5 & $\begin{array}{l}\text { Turnover rate of central bank governors based } \\
\text { on 5-year averages (de facto central bank } \\
\text { independence indicator). }\end{array}$ & $\begin{array}{l}\text { Author's calculations based on central bank websites and } \\
\text { Dreher et al. (2008; April } 2009 \text { update). Dreher's database is } \\
\text { available } \\
\text { http://www.uni-goettingen.de/en/datasets/89555.html }\end{array}$ \\
\hline CRED & $\begin{array}{l}\text { Domestic credit to private sector ratio in } \% \text { of } \\
\text { GDP. }\end{array}$ & $\begin{array}{l}\text { World Development Indicators (WDI) are now } \\
\text { available free on the World Bank's website at: } \\
\text { http://data.worldbank.org/ }\end{array}$ \\
\hline BMG & Broad money growth. & $\begin{array}{l}\text { World Development Indicators (WDI) are now } \\
\text { available free on the World Bank's website at: } \\
\text { http://data.worldbank.org/ }\end{array}$ \\
\hline $\mathrm{EXCH}$ & $\begin{array}{l}\text { De facto flexibility indicator of exchange rate, } \\
\text { comprised between } 1 \text { and } 14 \text { from the least to } \\
\text { more flexible exchange rate regime. }\end{array}$ & IMF's AREAR;Reinhart and Rogoff (2004). \\
\hline OPEN & $\begin{array}{l}\text { Trade openness (as the sum of exports and } \\
\text { imports of goods and services as a share of } \\
\text { GDP). }\end{array}$ & $\begin{array}{l}\text { World Development Indicators (WDI) are now } \\
\text { available free on the World Bank's website at: } \\
\text { http://data.worldbank.org/ }\end{array}$ \\
\hline POLITY2 & $\begin{array}{l}\text { Indicator of democracy taking values from }-10 \\
\text { (very autocratic) to }+10 \\
\text { (very democratic). }\end{array}$ & Polity IV Project \\
\hline
\end{tabular}

Appendix B. Descriptive Statistics

\begin{tabular}{|c|c|c|c|c|c|}
\hline Variables & Obs & Mean & Std.Dev. & Min & Max \\
\hline Inflation targeting countries & $(2000-2017)$ & & & & \\
\hline IT_PA & 6346 & .8159471 & $.3875 \quad 79$ & 0 & 1 \\
\hline IT_FF & 6346 & .8413174 & .3654087 & 0 & 1 \\
\hline Zscore & 4338 & 21.05445 & 122.3001 & -878.7543 & 3823.777 \\
\hline GDPpc_G & 6346 & 3.013804 & 3.390501 & -11.87729 & 11.25178 \\
\hline INF_1 & 6170 & 8.753257 & 11.4668 & -1.166896 & 95.00523 \\
\hline BMG & 6314 & 16.03091 & 16.24644 & -21.86383 & 160.8075 \\
\hline CRED & 6329 & 41.1373 & 32.42744 & 7.089964 & 160.1249 \\
\hline OPEN & 6346 & 66.7854 & 32.76909 & 22.10598 & 183.4276 \\
\hline $\mathrm{EXCH}$ & 1.729 & 11.20879 & 2.81403 & 2 & 14 \\
\hline TOR_5 & 4076 & .1621197 & .120847 & 0 & 6 \\
\hline POLITY2 & 6208 & 8.230831 & 1.575152 & -5 & 10 \\
\hline Non inflation targeting countries & $(2000-2017)$ & & & & \\
\hline IT_PA & 5745 & .9333333 & .2494655 & 0 & 1 \\
\hline IT_FF & 5745 & .8666667 & .3399642 & 0 & 1 \\
\hline Zscore & 3846 & 18.45226 & 87.79258 & -801.3274 & 3172.583 \\
\hline GDPpc_G & 5221 & 3.16843 & 41.9185 & -1050247 & 30.34224 \\
\hline INF_1 & 5745 & 17.20119 & 41.9185 & -2.302125 & 324.9969 \\
\hline $\mathrm{BMG}$ & 5506 & 21.7566 & 22.0519 & -3.048625 & 160.8075 \\
\hline CRED & 5598 & 38.22218 & 29.28844 & 3.540243 & 134.9998 \\
\hline OPEN & 5703 & 76.47439 & 65.62888 & 21.85242 & 439.6567 \\
\hline $\mathrm{EXCH}$ & 1670 & 6.921557 & 4.076759 & 1 & 15 \\
\hline TOR_5 & 3660 & .1920219 & .188554 & 0 & .8 \\
\hline POLITY2 & 5697 & 4.917149 & 4.576421 & -6 & 10 \\
\hline
\end{tabular}

Source: Author calculations

\section{Copyrights}

Copyright for this article is retained by the author(s), with first publication rights granted to the journal.

This is an open-access article distributed under the terms and conditions of the Creative Commons Attribution license which permits unrestricted use, distribution, and reproduction in any medium, provided the original work is properly cited. 